\title{
Early phenotypic and functional alterations in lymphocytes from simian immunodeficiency virus infected macaques
}

\author{
Christian Kneitz ${ }^{\mathrm{a}}$, Thomas Kerkau ${ }^{\mathrm{a}}$, Justus Müller ${ }^{\mathrm{b}}$, Cheick Coulibalyc, \\ Christiane Stahl-Hennig ${ }^{c}$, Gerhard Hunsmann ${ }^{c}$, Thomas Hünig and Anneliese \\ Schimpl ${ }^{\mathrm{a}}$ \\ "Institute of Virology and Immunobiology, University of Würzburg. PO Box 8700, \\ Versbacherstrasse 7, Germany \\ 'Institute of Pathology, University of Würzburg, Versbacherstrasse, Germany \\ ${ }^{\circ} G e r m a n$ Primate Center GmbH, Göttingen, Germany
}

(Accepted 27 July 1992)

\begin{abstract}
Kneitz, C., Kerkau, T., Müller, J., Coulibaly, C., Stahl-Hennig, C., Hunsmann, G., Hünig, T. and Schimpl, A., 1993. Early phenotypic and functional alterations in lymphocytes from simian im. munodeficiency virus infected macaques. Vet. Immunol. Immunopathol., 36: 239-255.

Phenotypic and functional changes in lymphocytes from rhesus monkeys (Macaca mulatta) were investigated during the first 6 months after infection with SIVmac 32H. Animals preimmunized with keyhole limpet hemocyanin (KLH) were sacrificed 1, 3, 6, 12, and 24 weeks post infection. Subset composition and function of lymphocytes from blood, spleen, lymph node and thymus were analysed. In addition to a rapid decline in CD4/CD8 ratios, a massive reduction in $\mathrm{CD} 29+\mathrm{CD} 4+$ cells was seen in the periphery. Although depletion of this subset was observed throughout the course of this experiment, the loss of proliferative $T$ cell responses was most pronounced very early after infection and partially recovered after Month 3 . Polyclonal cytotoxic responses were only slightly affected. In the thymus, a gradual, but moderate loss of CD4 + CD8 + immature thymocytes, and a relative increase in both CD4 + and CD8 + mature subsets was observed. Infectious virus was readily recovered from homogenates of lymph node and spleen, but not of thymus tissue. Interestingly, however, virus was detected in thymocytes from all infected animals by cocultivation with a simian immunodeficiency virus (SIV) susceptible cell line.
\end{abstract}

\section{ABBREVIATIONS}

$\mathrm{Ab}$, antibody; BSA, bovine serum albumin; BSS, balanced salt solution; DN, double negative; DP, double positive; FCS, fetal calf serum; KLH, keyhole limpet hemocyanin; mAb, monoclonal antibody, PBL, peripheral blood lymphocyte; PBS, phosphate buffered saline; SIV, simian immunodeficiency virus; SP, single positive.

Correspondence to: A. Schimpl, Institute of Virology and Immunobiology, University of Würzburg, PO Box 8700 , Versbacherstrasse 7, Germany. 
A key to the development of new therapeutic modalities and vaccine strategies against AIDS is a thorough understanding of its pathogenesis. Even though the later stages of the disease have been extensively studied (Miedema et al., 1990), little is known about the pathophysiological changes that occur immediately after infection (McCune, 1991). The obvious reason is that the time of infection is usually unknown and serological diagnosis only becomes possible 6-8 weeks post infection. Furthermore, the investigation of peripheral lymphatic organs such as spleen and lymph nodes is severely limited in HIV.-infected humans. Effects on the thymus of infected individuals also can usually only be studied in post mortem specimens. For that reason up to now, no complete study of the immunologic changes in blood and lymphatic organs during the early stages of HIV-infected humans has been performed. The SIV-infected rhesus monkey (Macaca mulatta) is a suitable animal model to study such questions, because there are striking similarities between the SIVinduced disease in rhesus monkeys and the HIV-induced disease in humans (Letvin et al., 1985; Beneviste et al., 1988; Desrosier and Ringler, 1989; Desrosier, 1990). Thus, these two genetically closely related viruses (Chakrabarti et al., 1987; Franchini et al., 1987) both use the CD4 molecule as receptor (Kannagi et al., 1985; Schnittman et al., 1989) and cause an immunodeficiency syndrome in their respective hosts (Letvin et al,, 1985; Baskin et al., 1988; Beneviste et al., 1988; Fultz et al., 1989). The most important difference seen so far is that SIV usually induces disease within 2 years after infection (Letvin et al., 1985; Beneviste et al., 1988; Fultz et al., 1989) while latency in HIV-infected humans is generally longer (Letvin and King, 1990). This difference greatly facilitates the study of the AIDS-like syndrome in rhesus monkeys.

In both humans (Bowen et al., 1985; Fahey et al., 1990) and macaques (Kannagi et al., 1986), a severe depletion of CD4 + cells has been described which, in human patients, correlates with the progression of the disease. In the residual CD4 + cells severe signalling defects have been found, which may extend to the CD8 + subset (Gale et al., 1990). Investigation of the CD29 $9^{\text {high }}$ (Schnittman et al., 1990) and/or CD44 positive (Willerford et al., 1990) T cell subpopulations of 'memory-cells' showed functional defects in both species and a greater viral burden as compared with CD29low $\mathrm{T}$ helper cells (Gallatin et al., 1989; Schnittman et al., 1990; Willerford et al., 1990). In monkeys, it was additionally shown that these 'memory-cells' were selectively lost during the course of infection (Gallatin et al., 1989; Murphey-Corb et al., 1989; Willerford et al., 1990). Because of these and other striking similarities between the disease induced by HIV in humans and by SIV in macaques, we have undertaken the present study of the rhesus monkey model to analyse the 
early phase of infection and the events taking place in organs usually not accessible in the humans.

\section{MATERIALS AND METHODS}

Animals

The rhesus macaques (Macaca mulatta) used in this study were of Chinese origin and kept at the German Primate Center, Göttingen as previously described (Stahl-Hennig et al., 1990). At the time of infection the monkeys were between 3 and 3.3 years of age (Table 1 ). All monkeys were seronegative for type-D-virus, STLV-1 (simian T-cell lymphotropic virus-1) and SIV. At Day 39 before infection they were immunized intramuscularly with $1 \mathrm{mg}$ keyhole limpet hemocyanin $(\mathrm{KLH})$ in alum with $10^{9}$ killed pertussis-organisms. Five animals were inoculated intravenously with $1 \mathrm{ml}$ of cell free stock, virus of SIVmac 251/32H (Cranage et al., 1990) containing 100 MID $_{\text {so }}$ (monkey infectious doses infecting $50 \%$ of recipients ). One additional animal served as a negative control. At Weeks $1,3,6,12$ and 24 after infection, individual animals were sacrificed and lymphocytes from blood, spleen, thymus and lymph nodes were isolated. The negative control was sacrificed 1 week before the end of the experiment.

\section{TABLE 1}

Date of birth, duration of infection, virus isolation, seroconversion and clinical symptoms in experimentally SIV mac infected rhesus monkeys

\begin{tabular}{|c|c|c|c|c|c|}
\hline $\begin{array}{l}\text { Animal } \\
\text { no. }\end{array}$ & $\begin{array}{l}\text { Date of } \\
\text { birth }\end{array}$ & $\begin{array}{l}\text { Sacrificed } \\
\text { at w.p.i. }\end{array}$ & $\begin{array}{l}\text { Isolation } \\
\text { of virus } \\
\text { w.p.i. }\end{array}$ & $\begin{array}{l}\text { Seroconversion } \\
\text { w.p.i. }\end{array}$ & $\begin{array}{l}\text { Clinical } \\
\text { symptoms }\end{array}$ \\
\hline 5027 & 15.3 .87 & $\begin{array}{l}23 \\
(\text { control })^{1}\end{array}$ & - & - & - \\
\hline 5130 & 16.7 .87 & 1 & 1 & - & - \\
\hline 5127 & 03.7 .87 & 3 & $>2$ & 3 & $\begin{array}{l}\text { lympha- } \\
\text { denopathy }\end{array}$ \\
\hline 5016 & 24.3 .87 & 6 & $>2$ & 4 & $\begin{array}{l}\text { persisting } \\
\text { lympha- } \\
\text { denopathy } \\
\text { (p.l.) }\end{array}$ \\
\hline 5017 & 07.4 .87 & 12 & $>2$ & 4 & p.l. \\
\hline 5029 & 07.3 .87 & 24 & $>2$ & 4 & p.l. \\
\hline
\end{tabular}

'Sacrificed at 23 weeks after experimental infection of the other animals. 


\section{Isolation and detection of virus}

Fragments of freshly prepared organs were homogenized in RPMI 1640 supplemented with antibiotics and centrifuged for $30 \mathrm{~min}$ at 3000 r.p.m. The cell free supernatants were added to C8166 indicator cells (Salahuddin et al., 1983). Peripheral blood lymphocytes (PBLs) were prepared as described (Stahl-Hennig et al., 1990) and co-cultivated with C8166 cells after 3 days of stimulation with phytohemagglutinin. The cultures were maintained over a period of 5 weeks and regularly inspected for the appearance of giant cells and syncytia formation. Virus replication in these cultures was confirmed by a reverse transcriptase assay (Stahl-Hennig et al., 1990). To investigate virus production in cultured cells from spleen and thymus, cell suspensions were prepared after careful removal of adhering lymphatic tissue. $5 \times 10^{5}$ thymocytes or spleen cells were cocultured with $1 \times 10^{4} \mathrm{C} 8166$-cells in $1.5 \mathrm{ml}$ RPMI 1640 (supplemented with L-glutamine $(2 \mathrm{mM})$, penicillin, streptomycin, and $10 \%$ fetal calf serum (FCS) (Biochrom, Berlin, Germany)) containing 1.00 U human rIL-2 $\mathrm{ml}^{-1}$. The cytopathic effect on the $\mathrm{C} 8166$ cells was determined by microscopic inspection. After $48 \mathrm{~h}$ of co-cultivation the supernatants were monitored in triplicates for viral antigen by an anti simian p27 ELISA (Coulter El., Hialeah, FL) according to the manufacturer's instructions.

\section{Cytofluorometry}

Cells were surface labelled by incubating $2 \times 10^{5}$ cells for $30 \mathrm{~min}$ at $4^{\circ} \mathrm{C}$ in $100 \mu \mathrm{l}$ phosphate buffered saline (PBS), $\mathrm{pH} 7.2$, containing $0.2 \%$ bovine serum albumin (BSA), $0.02 \%$ sodium azide and the respective antibodies. The cells were then washed in the same buffer. Indirect labelling was performed by adding PE-conjugated rat anti-mouse kappa antibody (BectonDickinson, Heidelberg, Germany). After another washing cycle and incubation with mouse IgG (Sigma, Deisenhofen, Germany, $10 \mu \mathrm{g} \mathrm{ml}^{-1}$ ) for 15 min, to block free binding sites of the mouse kappa reagent, cells were stained with a FITC-conjugated antibody for $15 \mathrm{~min}$. The cells were washed, fixed with $3.5 \%$ formaldehyde to inactivate SIV and analyzed in a FACScan flow cytometer (Becton-Dickinson, Heidelberg, Germany). Anti human monoclonal antibodies $(\mathrm{mAb})$, which crossreact with macaque lymphocytes, were obtained from the following sources: Coulter Immunology (Hialeah, FL): CD29 (4B4, 1:200), P. Rieber (München, Germany): CD4 (MT310), CD8 (MT122). The anti rhesus CD3 mAb (FN 18) was obtained from Primate Center TNO, Rijswijk, Netherlands. The latter antibody was purified and directly FITC-conjugated (Janossy et al., 1987). All antibodies were used at saturating concentrations. Appropriate negative controls were used to set the cut off points in dot plots and to calculate the fraction of positive cells. 
Cytotoxicity assay

PBL and lymphocytes prepared from spleen were cultured at $2 \times 10^{6} \mathrm{ml}^{-1}$ RPMI in the presence of ConA $\left(2.5 \mu \mathrm{g} \mathrm{ml}^{-1}\right)$ with or without $100 \mathrm{U}$ human rIL-2. After $72 \mathrm{~h}$ alpha-methyl-mannoside was added to a final concentration of $50 \mathrm{mM}$. After $1 \mathrm{~h}$, cells were washed three times and their cytotoxic activity was assessed in an antibody redirected $5 \mathrm{~h}{ }^{51} \mathrm{Cr}$ release assay using $\mathrm{R} 73$ cells as targets. These murine hybridoma cells produce an anti rat alpha/beta TCR antibody (Ab) (Hünig et al., 1989) crossreacting with macaque alpha/beta TCR. Target cells were labelled for $1 \mathrm{~h}$ at $37^{\circ} \mathrm{C}$ with $\mathrm{Na}_{2}\left[{ }^{51} \mathrm{Cr}\right] \mathrm{O}_{4}$ (DuPont, Dreieich, Germany). ${ }^{51} \mathrm{Cr}$ labelled $\mathrm{R} 73$ cells $\left(5 \times 10^{3}\right)$ were incubated in triplicate with $5 \times 10^{4}$ effector cells for $5 \mathrm{~h}$.

\section{TABLE 2}

Reisolation of SIVmac from different organs of rhesus monkeys sacrificed at times indicated. Tissue homogenates were tested for the presence of infectious virus except for PBL, which were assayed after coculture with C8166 cells. Both tests were carried out for spleen and thymus

\begin{tabular}{|c|c|c|c|c|c|c|}
\hline & \multicolumn{6}{|c|}{ Animal number } \\
\hline & 5130 & 5127 & 5016 & 5017 & 5029 & 5027 \\
\hline $\begin{array}{l}\text { Sacrifice } \\
\text { weeks p. } \\
\text { infection } \\
\text { Cervical }\end{array}$ & 1 & 3 & 6 & 12 & 24 & control \\
\hline $\begin{array}{l}\text { lymph nodes } \\
\text { Mesenterial }\end{array}$ & + & n.d. & + & + & + & - \\
\hline $\begin{array}{l}\text { lymph nodes } \\
\text { Inguinal }\end{array}$ & + & + & + & + & + & - \\
\hline $\begin{array}{l}\text { lymph nodes } \\
\text { Blood }\end{array}$ & + & + & + & + & + & - \\
\hline lymphocytes & + & + & + & + & + & - \\
\hline $\begin{array}{l}\text { Spleen } \\
\text { homogenized } \\
\text { co-culture }\end{array}$ & $\begin{array}{l}+ \\
+/>1.6\end{array}$ & $\begin{array}{l}+ \\
+/>1.6\end{array}$ & $\begin{array}{l}t \\
+/>1.6\end{array}$ & $\begin{array}{l}+ \\
+/>1.6\end{array}$ & $\begin{array}{l}+ \\
+/>1.6\end{array}$ & $\begin{array}{l}- \\
-/ 0.12\end{array}$ \\
\hline $\begin{array}{l}\text { Thymus } \\
\text { homogenized } \\
\text { co-culture } \\
\text { parotis } \\
\text { gonades } \\
\text { bone marrow }\end{array}$ & $\begin{array}{l}- \\
+/>1.6 \\
- \\
-\end{array}$ & $\begin{array}{l}- \\
+/>1.6 \\
- \\
- \\
-\end{array}$ & $\begin{array}{l}- \\
+/>1.6 \\
- \\
- \\
-\end{array}$ & $\begin{array}{l}- \\
+/>1.6 \\
- \\
- \\
-\end{array}$ & $\begin{array}{l}- \\
+/>1.6 \\
- \\
- \\
-\end{array}$ & $\begin{array}{l}- \\
-10.12 \\
- \\
-\end{array}$ \\
\hline
\end{tabular}

+ Refers to an observation to cytopathic effects and/or positive RT assay, the numbers are OD units determined in the p27 ELISA. Neg. co.: 0.12 OD units, pos. co.: 1.6 OD units. 


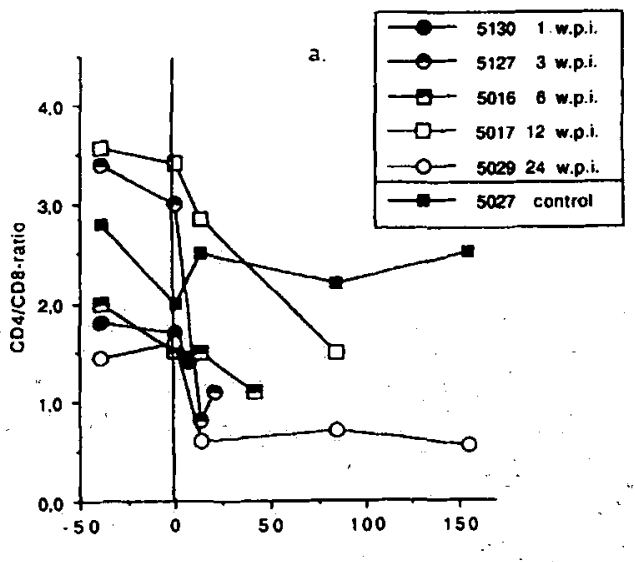

days post infection

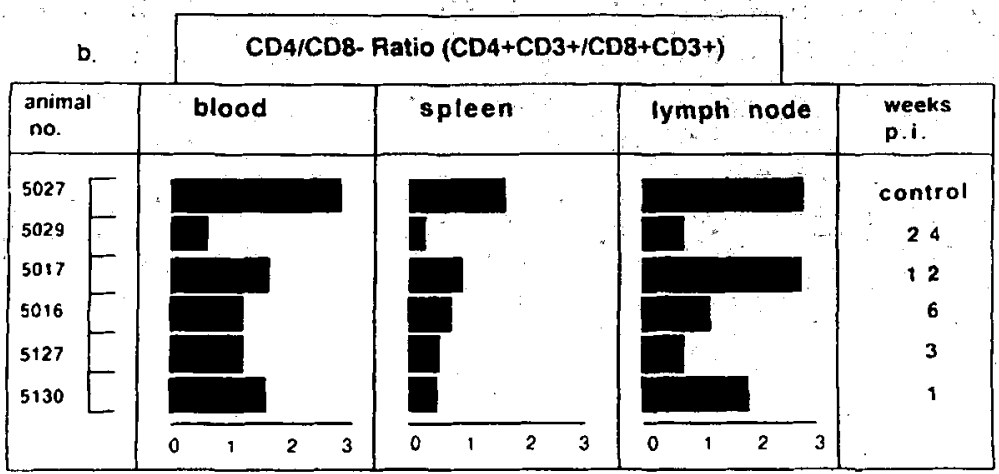

Fig. 1. (a) CD4/CD8-ratios in blood of macaques experimentally infected with SIVmac and of one control animal over time. PBL were isolated and phenotyped as described in 'Materials and Methods'. (b) CD4/CD8-ratios in lymphocytes from blood, spleen and mesenteric lymph nodes of experimentally infected rhesus monkeys sacrificed at various times after infection. Percentages of CD4 $+\mathrm{CD} 3+$ and $C D 8+C D 3+$ cells of $C D 3+$ cells are given.

\section{Proliferation assay}

\section{Antibody mediated proliferation}

Flat-bottom microtiter plates (Costar, Cambridge, MA) were coated over night at room temperature with rabbit anti-mouse IgG ( $40 \mu \mathrm{g} \mathrm{ml}^{-1}$ (Dako, Hamburg, Germany) ) in coating buffer (0.05M Na-Carbonate, pH 9.5). After washing three times with BSS (balanced salt solution), plates were incubated for $4 \mathrm{~h}$ at $4^{\circ} \mathrm{C}$ with $1 \mu \mathrm{g} \mathrm{ml}^{-1}$ anti-CD3 mAb (FN18, Nooj et al., 1986). After extensive washing with BSS, $2 \times 10^{5}$ cells in $0.2 \mathrm{ml}$ RPMI 1640 supplemented as described above, were added. 
b.
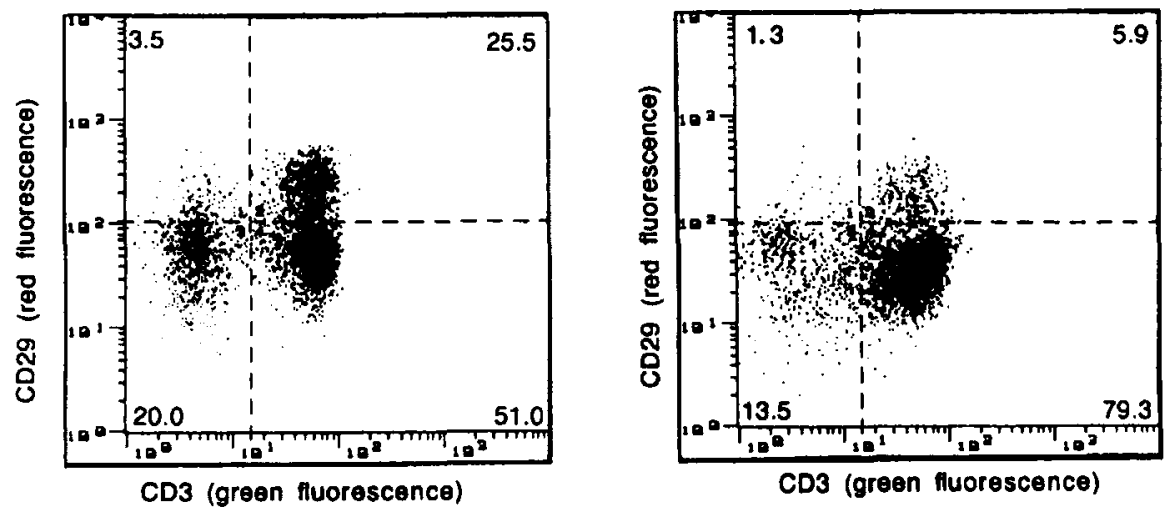

Fig. 2. Surface expression of CD29 (red fluorescence) vs. CD3 (green fluorescence) in lymphocytes isolated from the peripheral blood of (a) an uninfected animal; (b) an animal 12 weeks after infection with SIVmac.

\section{Antigen induced proliferation}

Lymphocytes $\left(2 \times 10^{5}\right)$ were placed in culture medium in U-bottom microtiter plates (Costar, Cambridge, MA) containing $100 \mu \mathrm{g} \mathrm{ml}^{-1} \mathrm{KLH}$. The cells were cultured at $37^{\circ} \mathrm{C}$ for $72 \mathrm{~h}$, with or without human rIL-2 (100 U rIL-2 $\mathrm{ml}^{-1}$ ) in a final volume of $200 \mu \mathrm{l}$. Each well was pulsed for $10 \mathrm{~h}$ with $25 \mu \mathrm{Ci}$ of $\left[{ }^{3} \mathrm{H}\right] \mathrm{dThd}$ (specific activity $2 \mathrm{Ci} \mathrm{mM}^{-1}$ ), harvested onto glass-fiber filter strips and the radioactivity incorporated into DNA was measured in a scintillation counter. The results are expressed as median c.p.m. of triplicate cultures.

\section{RESULTS}

Seroconversion and reisolation of virus from SIVmac $32 \mathrm{H}$ infected animals

A group of five age matched chinese rhesus monkeys was inoculated intravenously with cell free SIVmac $32 \mathrm{H}$. Animals were sacrificed at $1,3,6,12$ and 24 weeks post infection. The uninfected control animal from the same cohort was sacrificed 1 week before the end of the experiment. Seroconversion was observed in all five infected animals 3-4 weeks following infection with SIV (Table 1). At the same time lymphadenopathy was diagnosed, which was less severe than in later stages. The animals showed no signs of opportunistic infections or other overt disease at the time of sacrifice (i.e. up to 6 


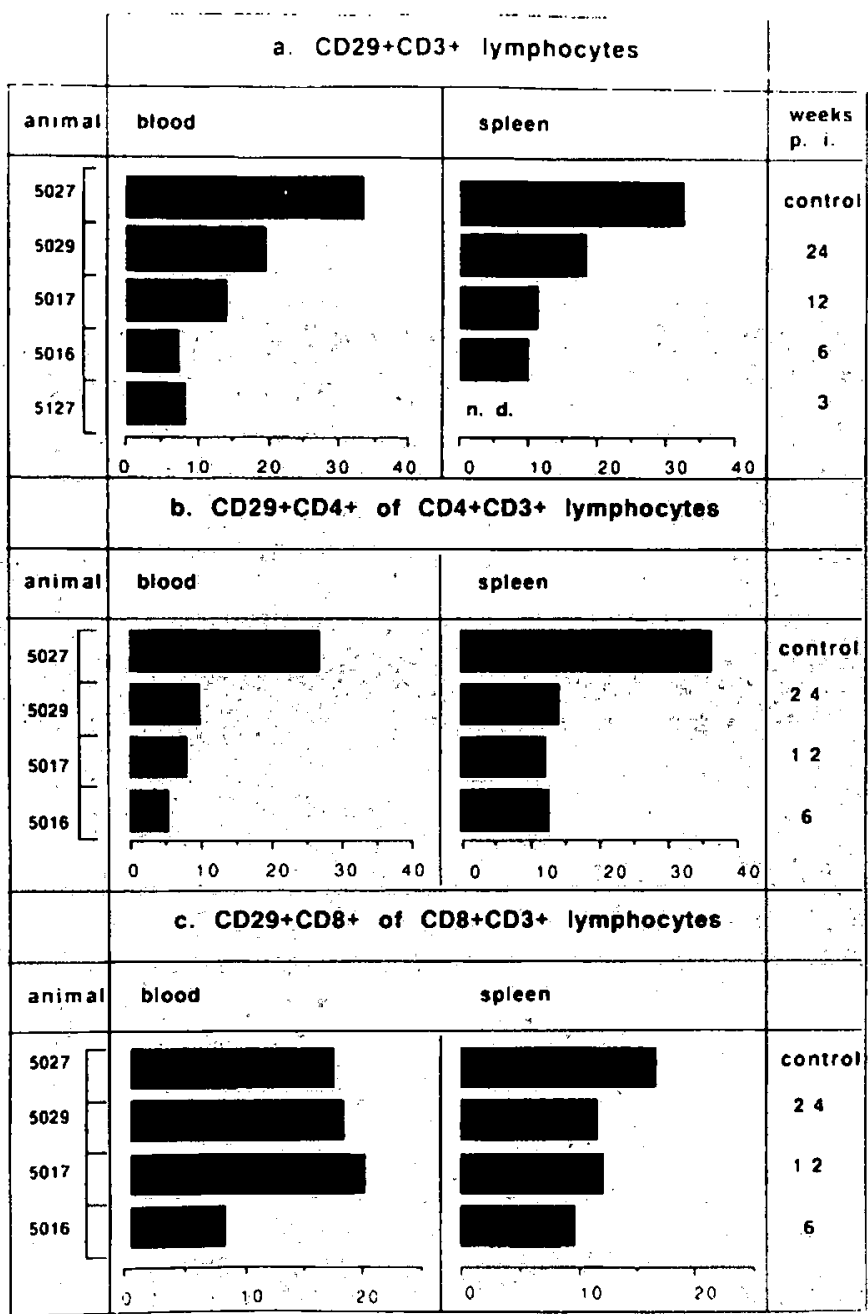

Fig. 3. Representation of CD29 + cells among T cell subsets of SIV infected animals. Lymphocytes were isolated from blood and spleen of the control and experimentally infected rhesus monkeys sacrificed at different times. (a) Percentage of CD29+CD3 + cells as percentage of total CD3 + cells. (b) Percentage of CD29+CD4 + lymphocytes of CD4+CD3 + cells. (c) Percentage of CD29+CD8 + lymphocytes of CD8 + CD3 + cells.

months post infection). The virus was successfully isolated from lymph nodes, spleen and peripheral blood lymphocytes from all experimental animals ( Table 2). The isolation of the virus from thymocytes will be discussed later. 


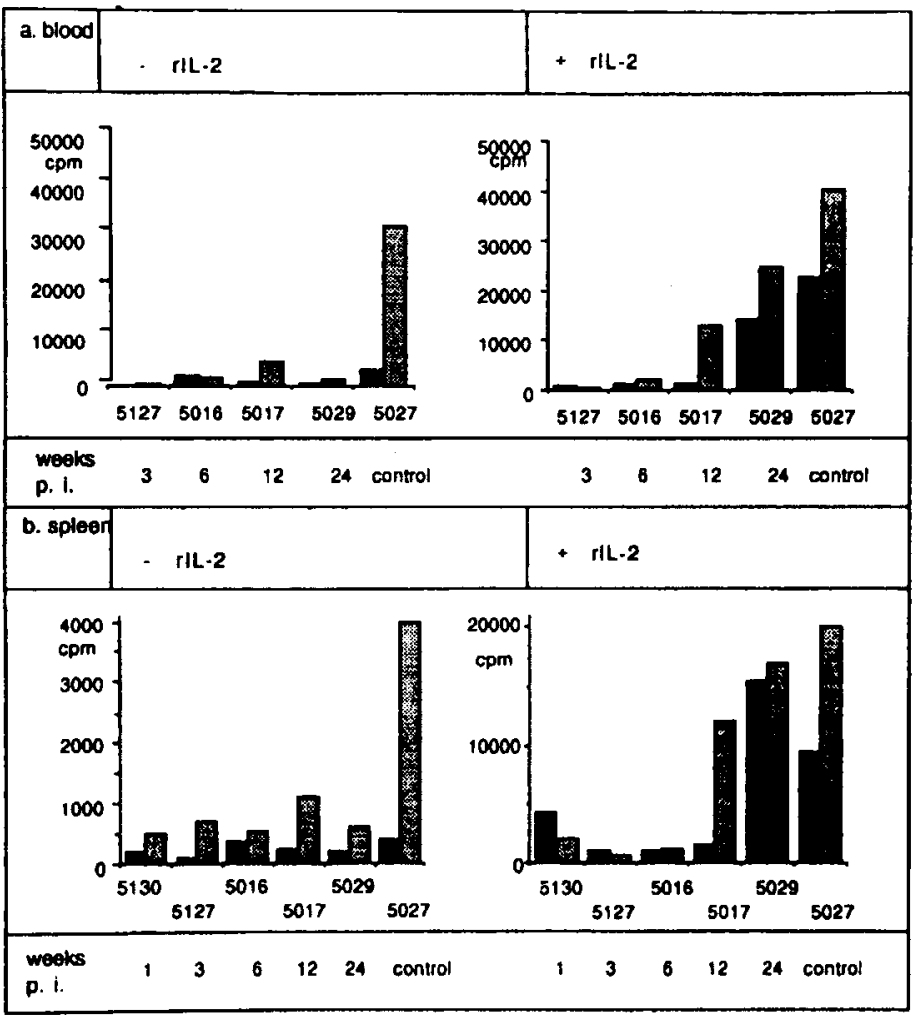

Fig. 4. Proliferation of T cells induced by KLH. Lymphocytes from (a) blood; (b) spleen of experimentally infected animals and the control were stimulated with $\mathrm{KLH}\left(50 \mu \mathrm{g} \mathrm{ml}{ }^{-1}\right)$ with and without exogenous rIL-2 $\left(100 \mathrm{U} \mathrm{ml}^{-1}\right)$ (bright bars). Background of cultures without $\mathrm{KLH}$ is shown as dark bars.

Phenotypic analysis of distinct $T$ cell subsets in blood, spleen and mesenteric lymph nodes

Figure 1 (a) shows CD4/CD8 ratios in peripheral blood before infection and at various time points until sacrifice of the individual animals. While the control animal maintained a constant $\mathrm{CD} 4 / \mathrm{CD} 8$ ratio of about 2.5 , the ratios declined in all infected animals, though to a varying degree and with different kinetics. By 2 weeks after infection the ratio had fallen below one: two out of the five infected animals. The reduction of CD4/CD8 ratios in spleen and lymph nodes was variable between the animals sacrificed at different time points (Fig. 1 (b)). The most drastic effect was observed in the animal sacrificed 3 weeks post infection. Evaluation of the CD29+ T-cell subset, which 


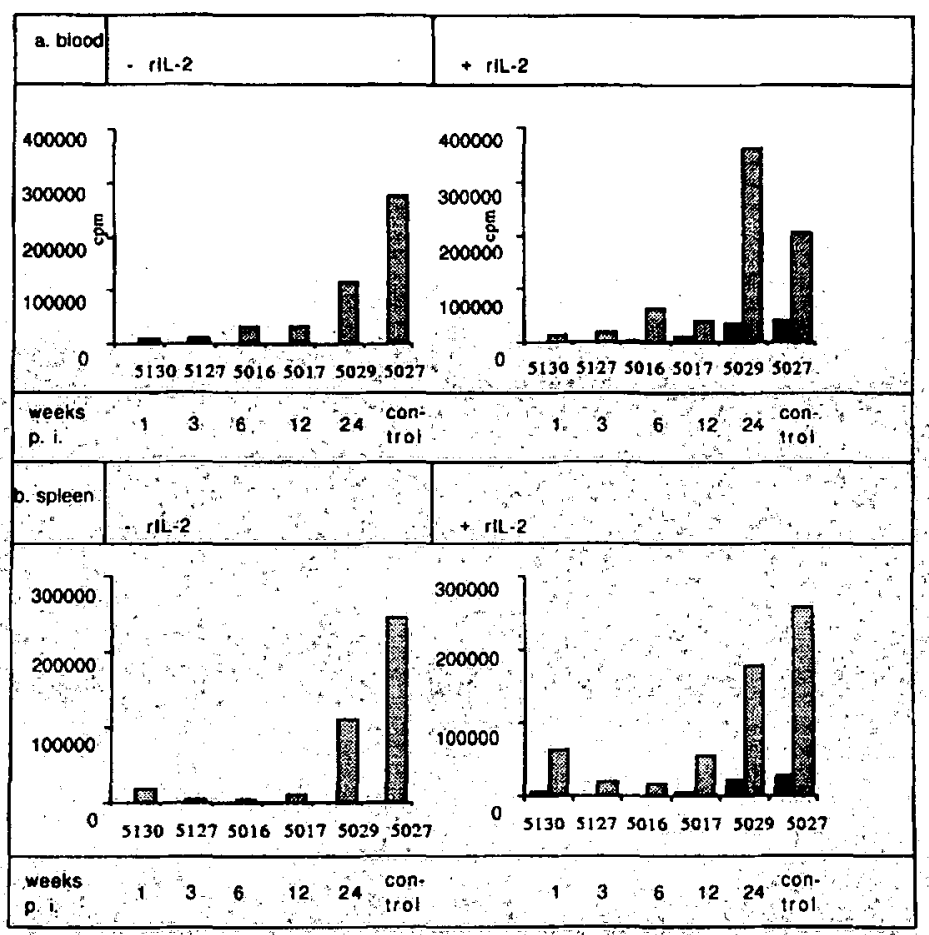

Fig. 5. Proliferation of $\mathrm{T}$ cells induced by immobilized anti-CD3 mAb. Lymphocytes from (a) blood; (b) spleen of experimentally infected animals and the control were stimulated with immobilized anti-CD3 mAb with and without exogenous rlL-2 (100 $\mathrm{U} \mathrm{ml}^{-1}$ ) (bright bars). Background of cultures without anti-CD3 mAb is shown as dark bars.

has been correlated with memory T-cells, at 3 weeks post infection revealed a nearly complete disappearance of $\mathrm{CD} 3+$ lymphocytes expressing this marker at a high level from the blood (Fig. 2).

Figure 3 summarizes the results obtained for all animals. There was a significant decrease of CD29+ cells in both the CD4+ and CD8 + subset of the animal sacrificed 6 weeks after infection. At later times, higher percentages of CD29+CD8 + lymphocytes were seen again, while the CD29+CD4+ cells were always low. Similar results were obtained with splenic lymphocytes though the depletion was less pronounced.

\section{$T$ cell proliferative response to $K L H$}

As a functional readout for memory $\mathrm{T}$ cells the proliferative response to the recall antigen KLH was studied. In Fig. 4 it is shown that $T$ cells isolated from blood (Fig. 4(a)) or spleen (Fig. 4(b)) of SIV infected animals had a decreased response to KLH compared with lymphocytes from the control ani- 


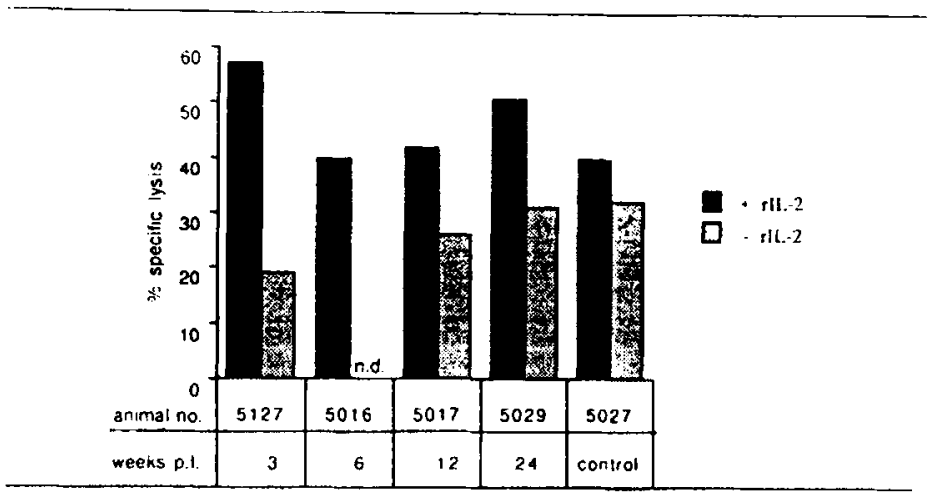

b. spleen

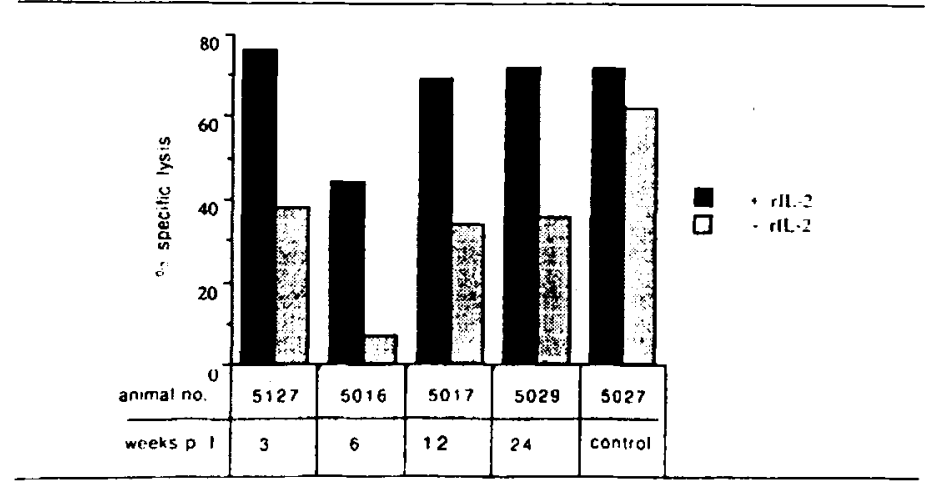

Fig. 6. Antibody redirected cytotoxicity of polyclonally activated lymphocytes isolated from (a) blood; (b) spleen of experimentally infected animals and the control. Cells were stimulated with ConA ( $5 \mu \mathrm{g} \mathrm{ml}^{-1}$ ) alone (dark bars) or with addition of exogenous rIL-2 (bright bars) for 3 days. Effector cells were incubated with ${ }^{51} \mathrm{Cr}$-labeled $\mathrm{R} 73$ target-cells for $5 \mathrm{~h}$ at different $\mathrm{E}: \mathrm{T}$ ratios only one of which $(30: 1)$ is shown.

mal. Addition of $100 \mathrm{U}$ rIL-2 partially reconstituted this defective response when cells from the animal sacrificed 12 weeks post infection were analysed. No effect of rIL-2 was seen however with cells from animals 6 weeks or earlier post infection.

\section{$T$ cell proliferative response to immobilized anti-CD3 antibody}

To investigate TCR mediated T cell responses at a polyclonal level, lymphocytes from blood and spleen were stimulated by crosslinked anti-CD3 mAb (FN18). Figure 5 indicates that the infected animals responded poorly compared with the control animal. Again this defect was partially overcome by 
TABLE 3

Distribution of $T$ cell subpopulations in the thymus at early times post infection with SIVmac. Percentages of subsets calculated from one and two colour flow cytometric analysis performed as described in 'Materials and Methods'

\begin{tabular}{|c|c|c|c|c|c|c|c|c|c|}
\hline $\begin{array}{l}\text { Animal } \\
\text { no. }\end{array}$ & w.p.i. & $\begin{array}{l}\mathrm{CD} 4- \\
\mathrm{CD} 8-\end{array}$ & $\begin{array}{l}\mathrm{CD} 4+ \\
\mathrm{CD} 8+\end{array}$ & $\begin{array}{l}\text { CD3 } \\
\text { low }\end{array}$ & $\begin{array}{l}\text { CD3 } \\
\text { high }\end{array}$ & $\begin{array}{l}\text { CD8+ } \\
\text { CD3 } \\
\text { high }\end{array}$ & $\begin{array}{l}\text { CD4- } \\
\text { CD8+ }\end{array}$ & $\begin{array}{l}\text { CD4+ } \\
\text { CD3 } \\
\text { high }\end{array}$ & $\begin{array}{l}\text { CD4 + } \\
\text { CD8 - }\end{array}$ \\
\hline 5130 & 1 & nd & nd & 48 & 12 & 4 & nd & 10 & nid \\
\hline 5127 & 3 & nd & nd & 59 & 9 & 4 & nd & 7 & nd \\
\hline 5016 & 6 & 6 & 78 & 52 & 8 & 3 & 8 & 6 & 8 \\
\hline 5017 & 12 & 8 & 69 & 42 & 16 & 10 & 10 & 10 & 12 \\
\hline 5029 & 24 & 11 & 62 & 41 & 23 & 11 & 10 & 11 & 17 \\
\hline 5027 & control & 3 & 82 & 57 & 10 & 5 & 5 & 6 & 9 \\
\hline
\end{tabular}

the addition of rIL-2 (Fig. 5). However, similar to the KLH induced response, no effect of rIL-2 was seen with cells taken at the earlier time points.

\section{Cytotoxic activity of polyclonally activated lymphocytes}

The capacity to generate cytotoxic alpha/beta $T$ lymphocytes was investigated in vitro. T lymphocytes from blood (Fig. 6(a)) and spleen (Fig. 6(b)) were polyclonally activated by ConA for 3 days and CTL activity was determined by measuring lysis of anti-alpha/beta TCR mAb producing hybridoma cells. In the absence of rlL-2, cytotoxic activity of the cells from infected animals was slightly diminished compared with cells obtained from the control animal. Addition of rIL-2 during polyclonal activation, raised the cytotoxic capacity of cells from infected animals to the level found in the control.

\section{Thymus}

In contrast to the other lymphoid organs investigated, the infectious virus could not be isolated from the thymus homogenates. However, after co-culture of thymocytes with rIL-2 and C8166 cells, productive infection of the indicator cells was observed and assessed by cytopathic effects and a p27 ELISA (Table 2) as described in 'Materials and Methods'.

The distribution of the 'double negative' (DN), 'double positive' (DP) and 'single positive' (SP) cells in the thymus as defined by their coreceptors CD4 and CD8 is shown in Table 3. Concomitantly with a slight decrease of DP lymphocytes in thymocytes from infected animals sacrificed 6 weeks or more post infection a relative increase in SP thymocytes was observed. In contrast to peripheral lymphoid organs there was no selective loss of CD4 SP cells. The decrease in DP cells was also reflected in a reduction of $C D 3^{\text {low }}$ 
(immature) and a relative increase in $\mathrm{CD} 3^{\text {high }}$ (mature) thymocytes. Morphologic analysis also showed a cortical depletion which indicates a diminution of immature thymocytes (Müller et al., 1992).

\section{DISCUSSION}

The present study was undertaken to determine quantitative changes of lymphocyte subsets and functional alterations in the immune response during the early phase of SIVmac $32 \mathrm{H}$ infection in rhesus monkeys. In addition to pathophysiological alterations in peripheral blood lymphocytes this animal model also allowed us to investigate lymphocytes in spleen, lymph nodes and thymus.

The number of CD4 + cells and the CD4/CD8-ratio, in peripheral blood lymphocytes, are well accepted immunological parameters to assess the course of HIV- (Fahey et al., 1984) or SIV- (Letvin and King, 1990) induced disease. This was confirmed in the present study. A clear reduction in the representation of CD4+ lymphocytes in blood and lymphatic organs was observed very early after infection, although it was not manifest to the same extent in all animals. In addition we found a very early (at 3 weeks post infection, the first time point at which this marker was examined) and strong diminution of CD29+ T-lymphocytes in the blood. Both CD29+CD4+ and $\mathrm{CD} 29+\mathrm{CD} 8+$ cells showed an initial decline (Fig. 3 ). However, while the frequency of the CD29+CD4+ lymphocytes was low at all time points investigated $(6,12$ and 24 weeks post infection), the CD29+CD8 + lymphocytes were found to be normally represented in animals sacrificed at 12 or 24 weeks post infection. The depletion of CD29+CD4+ cells is in agreement with results reported by Schnittman et al. (1990) for HIV-1 positive humans and Willerford et al. (1990) for SIVmac rhesus monkeys. Schnittman et al. (1990) suggested that the decline of CD29+ cells in HIV positive individuals was due to the preferential replication of HIV in these cells. A very early loss of CD29 + CD4 + cells from the blood of SIVsm infected macaques has also been noted by Murphey-Corb et al. (1989). The low level of CD29+CD8 + cells in blood and spleen of the animal sacrificed 6 weeks post infection was not seen in the other monkeys at later times. While it cannot be excluded that the low frequency of CD29+CD8 + lymphocytes in one animal could reflect individual variations, it may, on the other hand, be a very early effect of SIV infection. Thus, immunoregulatory mechanisms that are part of the antiviral response, impairment of $C D 4+T$ cell function, or a direct effect of the virus could all modulate homing behaviour and marker expression of the various subsets, including the CD29+CD8 + subset.

Since it has been shown (Morimoto et al., 1985; Merkenschlager et al., 1988; Akbar et al., 1991) that cells responding to soluble recall antigens in vitro express high levels of CD29, it was not surprising that the proliferative 
response to $\mathrm{KLH}$ was rapidly lost in spleen and blood lymphocytes after infection. The response to immobilized anti-CD3 antibodies was also impaired (Fig. 5). The fact that the ability to proliferate seems to be more strongly reduced than the frequency of CD4 + cells, suggests that the residual cells may exhibit signalling defects at a very early stage after infection. Whether this is directly related to the tropism of the virus or its envelope product for CD4 + cells (Kannagi et al., 1985; Schnittman et al., 1989) or indirectly caused by immunosuppressive effects of acute virus infections remains open. In this context it is worth noting that although CD4/CD8 ratios remain low or even decline further, the response to $\mathrm{KLH}$ and crosslinked $\mathrm{CD} 3$ antibodies tends to partially recover after 12 weeks of infection.

In contrast to the impaired proliferative responses, generation of cytotoxic alpha/beta-positive $T$ cells after polyclonal stimulation of splenic lymphocytes with ConA was only slightly affected (Fig. 6).

Besides the well documented effects of HIV or SIV infection on the peripheral immune system, interference of virus infection with $T$ cell development seems possible. Infection of thymocytes with immunodeficiency viruses could contribute to the peripheral decline in immune function in two ways: reduction of $T$ cell output (in young individuals) and infection of maturing lymphocytes, including those that will aquire the CD4-CD8 + phenotype, during transit through the CD4 + CD8 + compartment.

The finding that HIV can infect human thymocytes in vitro (DeRossi et al., 1990; Schnittman et al., 1990) is compatible with such mechanisms. Although in our present study no infectious virus was found in thymus homogenates (which is in contrast to homogenates from peripheral lymph nodes) co-culture of thymocytes from infected animals with a susceptible cell line demonstrated that the virus could be recovered quite readily (Table 2 ), indicating that the thymus is in fact a target for the virus in vivo. This has recently also been described by Baskin et al. (1991). However, the form (dormant or replicating) in which the virus is present and which of the various $T$ cell subpopulations are infected in vivo remains to be determined. Interestingly, the ratio of the mature CD4 SP and CD8 SP thymocyte subsets was not markedly affected by virus infection, and the fraction of double positive thymocytes was only slightly reduced. Whether this reduction in DP cells (Table 3 ), which later, during infection, may lead to the pathomorphological changes described as cortical atrophy (Baskin et al., 1991; Müller et al., 1992) is due to virus infection per se or to indirect effects, is difficult to assess in vivo, but could possibly be addressed using organ cultures. To better understand the role of the thymus in the pathogenesis of AIDS, particularly the effects of thymus infection on the course of disease in children and juveniles, further investigations will be aimed at determining the stage and the extent of infection in the thymocyte subpopulations. 


\section{ACKNOWLEDGEMENTS}

This study was supported by the Deutsche Forschungsgemeinschaft, Grant: Kn 273/2-1, the Verbundprojekt BGA II-068-88 and the Fonds der Chemischen Industrie. We thank Ursula Sauer for expert technical assistance and Dr. Peter Rieber for kindly providing us with mAbs MT310 and MT122.

\section{REFERENCES}

Akbar, A.N., Salmon, M. and Janossy, G., 1991. The synergy between naive and memory cells during activation. Immunol. Today, 12: 184-188.

Baskin, G.B., Murphey-Corb, M., Watson, E.A. and Martin, L.N., 1988. Necropsy findings in rhesus monkeys experimentally infected with cultured simian immunodeficiency virus (SIV)/ Delta. Vet. Pathol., 25: 456-467.

Baskin, G.B., Murphey-Corb, M., Martin, L.N., Davison-Fairburn, B., Hu, F.S. and Kuebler, D., 1991. Thymus in simian immunodeficiency virus-infected rhesus monkeys. 65: 400-407.

Beneviste, R.E., Morton, W.R., Clark, E.A., Tsai, C.-C., Ochs, H.D., Ward, J.M., Kuller, L., Knott, W.B., Hill, R.W., Gale, M.J. and Thouless, M.E., 1988. Inoculation of baboons and macaques with simian immunodeficiency virus/Mne, a primate lentivirus closely related to human immunodeficiency virus type 2. J. Virol., 62: 2091-2101.

Bowen, D.L., Lane, H.C. and Fauci, A.S., 1985. Immunopathogenesis of the acquired immunodeficiency syndrome. Ann. Int. Med., 103: 704-709.

Chakrabarti, L., Guyader, M., Alizon, M., Daniel, M.D., Desrosier, R.C., Tiollais, P. and Sonigo, P., 1987. Sequence of simian immunodeficiency virus from macaque and its relationship to other human and simian retroviruses. Nature, 328: 543-547.

Cranage, M.P., Cook, N., Johnstone, P., Greenway, J., Kitchin, P.A., Scott, J.E. and Almond, N., 1990. In vitro titration of infectivity and development of an experimental vaccine. In: $H$. Schellekens and M. Horzinek (Editors), Animal Models in AIDS, Elsevier Science Publishers, pp. 103-107.

DeRossi, A., Calabro, M.L., Panozzo, M., Bernardi, D., Caruso, D., Tridente, G. and ChiecoBianchi, L., 1990. In vitro studies of HIV-1 infection in thymic lymphocytes: A putative role of the thymus in AIDS pathogenesis. AIDS Res. Hum. Retroviruses, 6: 287-297.

Desrosier, R.C., 1990. The simian immunodeficiency viruses. Annu. Rev. Immunol., 8: 557578.

Desrosier, R.C. and Ringler, D.J., 1989. The use of simian immunodeficiency viruses for AIDS research. Intervirology, 30: 301-312.

Fahey, J.L., Taylor, J.M.G., Detels, R., Hofmann, B., Melmed, R., Nishanian, P. and Giorgi, J.V., 1990. The prognostic value of cellular and serologic markers in infection with human immunodeficiency virus type 1. N. Engl. J. Med., 322: 166-172.

Fahey, J.L., Prince, H., Weaver, M., Groopmann, J., Visscher, B., Schwartz, K. and Detels, R., 1984. Quantitative changes in T helper or $T$ supressor cytotoxic lymphocyte subsets that distinguish acquired immunodeficiency syndrome from other subset disorders. Am. J. Med., 76: $95-100$.

Franchini, G., Gurgo, C., Guo, H.-G., Gallo, R.C., Collalti, E., Fargnoli, K.A., Hall, L.F., WongStaal, F. and Reitz, M.S., 1987. Sequence of simian immunodeficiency viruses and its relationship to the human immunodeficiency viruses. Nature, 328: 539-543.

Fultz, P.N., McClure, H.M., Anderson, D.C. and Switzer, M.W., 1989. Identification and biologic characterisation of an acutely lethal variant of simian immunodeficiency virus from sooty mangabeys (SIV/SMM). AIDS Res. Hum. Retroviruses, 5: 397-409. 
Gale, M.J., Ledbetter, J.A., Schieven, G.L., Jonker, M., Morton, W.R., Benveniste, R.E. and Clark, E.A., 1990. CD4 and CD8 T cells from SIV-infected macaques have defective signaling responses after perturbation of either $C D 3$ or $C D 2$ receptors. Int. Immunol., 2: 849-858.

Gallatin, W.M., Gale, M.J., Hoffman, P.A., Willerford, D.M., Draves, K.E., Benveniste, R.E., Morton, W.R. and Clark, E.A., 1989. Selective replication of simian immunodeficiency virus in a subset of CD4 positive lymphocytes. Proc. Natl. Acad. Sci., 86: 3301-3305.

Hünig, T., Wallny, H.-J., Hartley, J.K., Lawetzky, A. and Tiefenthaler, G., 1989. A monoclonal antibody to a constant determinant of the rat $T$ cell antigen receptor that induces $T$ cell activation. J. Exp. Med., 169: 73-86.

Janossy, G. and Amlot, P., 1987. In: G.G.B. Klaus (Editor), Lymphocytes. IRL Press, Oxford, pp. 42-44.

Kannagi, M., Yetz, J.M: and Letvin, N.L., 1985. In vitro growth characteristics of simian Tlymphotropic virus type III. Proc. Natl. Acad. Sci., 82: 7053-7057.

Kannagi, M., Kiyotaki, M., Desrosiers, R.C., Reimann, K.A., King, N.W., Waldron, L.M. and Letvin, N.L., 1986. Humoral immune responses to T cell tropic retrovirus simian T lymphotropic virus type III in monkeys with experimentally induced acquired immune deficiencylike syndrome. J. Clin. Invest., 78: 1229-1236.

King, N., Chalifoux, L.Y., Ringler, D.J., Wyand, M.S., Sehgal, P.K., Daniel, M.D., Letvin, N.L., Desrosiers, R.C., Blake, B.J. and Hunt, R.D., 1990. Comparative biology of natural and experimental SIV mac infection in macaque monkeys: A review. J. Med. Primatol., 19: 109118.

Letvin, N. and King, N.W., 1990. Immunologic and pathologic manifestations of the infection of rhesus monkeys with simian immunodeficiency virus of macaques. J. Acq. Imm. Def. Syndr., 3: 1023-1040.

Letvin, N.L., Danièl, M.D., Sehgal, P.K., Desrosiers, R.C., Hunt, R.D., Waldron, L.M., MacKey, J.J., Schmidt, D.K., Chalifoux, L.V. and King, N.W., 1985. Induction of AIDS-like disease in macaque monkeys with T-cell tropic retrovirus STLV-III. Science, 230: 71-73.

McCune, J.M., 1991. HIV-1: The infective process in vivo. Cell, 64: 351-363.

Merkenschlager, M., Terry, L., Edwards, L. and Beverly, P.C.L., 1988. Limiting dilution analysis of proliferative responses in human lymphocyte populations defined by the monoclonal antibody UCHLI: Implications for differential CD45 expression in T cell memory formation. Eur. J. Immunol., 18: 1653-1661.

Miedema, F., Tersmette, M. and van Lier, R.A.W., 1990. AIDS pathogenesis; a dynamic interaction between HIV and the immune system. Immunol. Today, 11 (8): 293-297.

Morimoto, C., Letvin, N.L., Distaso, J.A., Aldrich, W.R. and Schlossman, S.F., 1985. The isolation and characterization of the human suppressor inducer T cell subset. J. Immunol., 134: $1508-1515$.

Müller, J., Krenn, V., Schindler, C., Crub, S., Stahl-Hennig, C. et al., 1992. Alterations of thymic cortical epithelium and interdigitating dendritic but no increase of thymocyte cell death in the early course of SIV infection. Am. J. Pathol., submitted.

Murphey-Corb, M., Martin, L.N., Davison-Fairburn, B., Montelaro, R.C., Miller, M., West, M., Ohkawa, S., Baskin, G.B., Zhang, J.-Y., Putney, S.D., Allison, A.C. and Eppstein, D.A., 1989. A formalin inactivated whole SIV vaccine confers protection in macaques. Science, 246: 1293-1297.

Nooij, F.J.M., Jonker, M. and Balner, H., 1986. Differentiation antigens on rhesus monkey lymphocytes Il. Characterisation of RhT3, a CD3-like antigen on T cells. Eur. J. Immunol., 16: $981-984$.

Salahuddin, S.Z., Markham, P.D., Wong-Staal, F., Franchini, G., Kalynaraman, V.S. and Gallo, R.C., 1983. Restricted expression of human T-cell leukämia-lymphoma virus (HTLV) in transformed human umbilical cord blood lymphocytes. Virology, 129: 51-64.

Schnittman, S.M., Posallidopoulos, M.C., Lane, H.C., Thompson, L., Baseler, M., Massari, F., 
Fox, C.H., Salzman, N.P. and Fauci, A.S., 1989. The reservoir for HIV-1 in human peripheral blood is a $T$ cell that maintains expression of CD4. Science, 2: 305-308.

Schnittman, S.M., Lane, H.C., Greenhouse, J., Justement, J.S., Baseler, M. and Fauci, A.S., 1990a. Preferential infection of CD4 positive memory $T$ cells by human immunodeficiency virus type 1: Evidence for a role in the selective T-cell functional defects observed in infected individuals. Proc. Natl. Acad. Sci., 87: 6058-6062.

Schnittman, S.M., Denning, S.M., Greenhouse, J.J., Justement, J.S., Baseler, M., Kurtzberg, J., Haynes, B.F. and Fauci, A.S., 1990b. Evidence for susceptibility of intrathymic T-cell precursors and their progeny carrying T-cell antigen receptor phenotypes TCR $\alpha / \beta^{+}$and TCR $\gamma /$ $\delta^{+}$to human immunodeficiency virus infection: A mechanism for $\mathrm{CD}^{+}$(T4) lymphocyte depletion. Proc. Natl. Acad. Sci., 87: 7727-7731.

Stahl-Hennig, C., Herchenröder, O., Nick, S., Evers, M., Stille-Siegener, M., Jentsch, K.-D., Kirchhoff, F., Tolle, T., Gatesman, T.J., Lüke, W. and Hunsmann, G., 1990. Experimental infection of macaques with HIV-2 ${ }_{\text {ben }}$, a novel HIV-2 isolate. AIDS, 4: 611-617.

Willerford, D.M., Gale, M.J., Beneviste, R.E., Clark, E.A. and Gallatin, W.M., 1990. Simian immunodeficiency virus is restricted to a subset of blood CD4 positive lymphocytes that includes memory cells. J. Immunol., 144: 3779-3783. 